\title{
Prospective and Challenges: Tourism Development at Meghauli
}

\author{
${ }^{1}$ Ph.D Scholar, Mewar University \\ Gangrar, Chittorgar Rajasthan India
}

\author{
Bishwa Raj Subedi ${ }^{1}$
}

\begin{abstract}
Background: Meghauli is known as one of the richest villages in Nepal in terms of floura and fauna. It is the heart of beauty that is totally unexpected in a country known mainly for a majestic and powerful location teeming with wild life. It hosts one of Asia's finest national parks, renowned for its dense concentration of wild life. Tourists can be attracted from all over the world to view the floura and fauna along with other attractions. Objectives: The objective to study the prospective and the challenges of tourism development in Meghauli. Methodology: Descriptive and analytical research designs have been followed. Required information for the study has been obtained both from secondary and primary sources. Result: Some of the prime tourism attractions of Meghauli are the rare flora and fauna, natural beauty, villages, community forest, cultural diversity, religious places, rivers, lakes, world heritage CNP, ecopark, picnic park and the sunset view point. Due to these various tourism attractions, Meghauli has potential for the establishment of magnificent resorts and future development of tourism. Conclusion: Meghauli is situated by the side banks of CNP and two big rivers: Rapti and Narayani. The community forest and CNP are home to many types of wildlife. Almost 500 species of birds and wide variety of vegetations can be found in Meghauli. The dense forests, grasslands, rivers and many lakes embrace a balanced park ecology providing an environment suitable for animals, birds, insects and other forms of life. But it is not managed naturally and properly.
\end{abstract}

KEY WORDS: Meghauli, National Park, Prospectus and challenges, Tourism

\section{INTRODUCTION}

Nepal is very rich in natural resources; it offers wonderful scenes, sights and various diversity of culture and customs are available. It lies between 80.4 ' and 88.12' longitude east with the latitude of $26.22^{\prime}$ and 30.27 ' north and is located between the Republic of China along northern border and the fertile plains of India to the east, west and south. It has a total area of 1, 47,181 square $\mathrm{km}$ in width from north to south and is roughly rectangular in shape (CBS, 2001). Every part of the country provides enchantment in the form of mountains, terraced farmlands of hillsides and forests full of wildlife, flowers and birds.

Chitwan is a multi-features district in Nepal. It lies in the Narayani zone of Central Development Region and is known as the district of migrants from all over the country. It is full of natural and cultural resources. Among the many VDCs of Chitwan, the most beautiful and attractive VDC is Meghauli. In the rank of such villages, Meghauli lies in the top places because of its location. 
Meghauli is $25 \mathrm{~km}$ far from Bharatpur, which is the head quarter of Chitwan district. It has a land area of 77.18 square $\mathrm{km}$. It is known as one of the richest villages of Nepal in terms of wildlife and birds. Meghauli is surrounded about $25 \mathrm{~km}$ boundaries by Chitwan National Park and two big rivers; Narayani and Rapti in south, west and north. It lies in the Buffer zone area.Sukranagar VDC and Divyanagar VDC lie in the eastern border of Meghauli. The population of Meghauli is about 14,699 and it has 2598 households. (Participatory District Tourism Development and Management Plan, BS 2062/63-2066/67). It lies $172 \mathrm{~km}$ away from Kathmandu. Meghauli is a mine of nature and culture. Thus, it can be developed as a "Model Village Tourism" (Pradhanaga, Surendra Bhakta, B.S. 2062).

Meghauli is more attractive than other places around the National park for wildlife safari and bird watching. It has excellent potential for the establishment of magnificent resorts and future development of nature tourism. Rafters, after their long, exciting and adventurous white water trip can come to rest here and witness the diverse wildlife, panoramic views of the Himalayas and sunset on the Narayani and Rapti River. It is thus, emerging as an alternative tourism destination of Sauraha (Koirala, 2057).

Mostly Tharus, Brahmin, Sharki, Kumal, Newar, Gurung, Magar, Tamang, Bhote and Mushar reside in Meghauli. Among them the most populated tribe is that of the Tharu, who are thought to be the earliest inhabitants of Terai or 'Bhumi Putra.'

The main occupation of the people living in this village is agriculture. Few others are involved in business and government jobs. But, nowadays the majority of the populations believe that the development of the village depends on the development of tourism industry. The geographical location and its closeness to the national park are the reasons for developing tourism industry.

\section{JUSTIFICATION OF THE STUDY}

This study is intended to serve as the guideline for future tourism development in the country, keeping Meghauli in focus. Preparing a document on tourism prospects and challenges of tourism development in Meghauli is a new research study. In earlier days, tourism development used to take place virtually without planning and as a result most areas experienced more negative impacts as compared to the benefits. This study envisions creating a model in tourism development at new destinations after addressing key issues and potentialities based on site surveys, feasibility and attractions of the areas. The document will be helpful for working out tourism planning and policies as for differences stakeholders, ruler academicians, bureaucrats, Village Development Committee (VDC), District Development Committee (DDC), Chitwan Tourism Development Committee (CTDC), Nepal Tourism Board (NTB) Meghauli Tourism Development Committee (MTDC) and Meghauli Consumer Committee (Buffer Zone). Most of the statistical datas and required information have been collected through primary sources. Questionnaires were prepared to generate realistic and accurate datas from local people, 
hotel owners and tourists. The respondents were requested to fill up the questionnaires. In the case of uneducated respondents, the questions were asked and answers were filled by the researcher.

\section{METHODOLOGY}

Research methodology is the most important aspect of research work and is a way to systematically solve research problems. It facilitates the research work and provides reliability and validity to it. To meet the objectives of this study, descriptive/analytical research design has been followed. Information required for the study was obtained both from secondary and primary sources and they have been analyzed with the help of table. It deals with the analysis of data collected through questionnaires provided to tourists, local people and hotel owners of Meghauli. During the 15 days of survey 125 tourists had visited Meghauli. Among them 50 tourists were selected and interviewed. All the tourists were foreigners.

The data collected through the questionnaires were classified and tabulated according to the needs of research.

\section{Present Status of Tourism at Meghauli Eco-park}

Community forest by the Meghauli airport is one of the attempts of the village people, who are always thinking for the betterment of this area in terms of tourism and ecology. The community forest occupies about 60 acres of land. It is being improved in a way through which it can be an interesting and refreshing place to the visitors. Meghauli Tourism Development Committee has started to lunch its own program for the betterment of this locality and its tourism sector. 'Eco-park' inside the Radha Krishna community forest near the airport is under construction. It is estimated to spread in about 6 acres of land and aims to provide extra facilities to the tourist. Meghauli is an entertainment spot featuring nature and culture. The Tharu cultural museum is one of the major attractions inside the Eco-park. The Orphan Wild Animal Center, Children Park and natural zoo are also equally attractive for visitors. The crocodile breeding center is under construction.

\section{Sun-set View Point}

Sun-set view point at Meghauli is a concept that can be developed for visitors' satisfaction. It is surrounded triangularly by the riverside and Chitwan national park. It is $8 \mathrm{~km}$ far from Meghauli airport. Tourism is a composite of activities facilities, services and industries that deliver a travel experience in the form of transportation, accommodation, eating and drinking establishment, recreation, cultural experiences etc. Sun-set view point offers entertainment to the nature lovers. 
Tourists can view sights at close quarters on elephant back excursions and take nature walks, canoe trips and jungle walks. The marvelous sights of forest with slopes and colored butterflies can be sighted in the community forest in winter as well as spring time.

\section{Meghauli Tharu Community Home Stay}

Home Stays are famous in ward no. 5 of Meghauli VDC. It is nearby the airport. The houses of this village are built in traditional manner. Most of the houses are built using local raw materials like bamboo and caters to tourists who have keen interest to view the natural and cultural heritage of destination. The minimum requirements of the house which can be converted into home-stay are: they should have at least 2 beds, 1 toilet, an advance store, clean drinking water and a clean surrounding etc.

Tourists can enjoy evenings with the host family by interacting, eating local cuisine and sleeping on their traditionally designed beds. The choice of food is confined among the local available food offered. Apart from the usual cultural performances performed during festivals, visitors can enjoy the cultural programs upon request with the committee. The guests can have a look of local indoor rituals with their host family and go on a village tour to see the life style, tradition and customs of the people.

\section{Picnic Park in Bardaha Community Forest}

Picnic Park is a beautiful spot on the bank of the Narayani River in Bardaha community forest. This forest is popular for tigers. Local people try to develop Picnic Park for domestic tourist attraction. The local community forest handled by the user group is the most managed one, providing shelter to many wild species. The area can be developed as a tourist destination in coordination with Meghauli Tourism Development Committee (MTDC). The people can be benefitted from the forest and tourists can enjoy the beauty of the picnic park. The community forest can be improved as green village tourist centers. Nature conservation is the prime objective of the national park management and with the support of the locals it can be developed into a green belt of vegetation.

\section{World Elephant Polo in Meghauli}

Meghauli is quite famous in terms of sport tourism. It conducts elephant polo in every two years. The World Elephant Polo Association [WEPA] was formed in 1982 at Tiger Tops Jungle Lodge in Chitwan National Park. The first game was played on the edge of the National Park.

\section{Rafting in Narayani River}

The river is regarded as a form of god and used for the purpose of various religious rituals such as cremation under both Hinduism and Buddhism. A river trip is often an adventure and even an amateur with little sense of adventure can enjoy it. 
Rafting in Nepal is a journey on the torrential river on an inflatable rubber boat. A river trip also provides opportunity for geological surveys and fishing. River trips provide best ways to explore a country's natural as well as ethno-cultural heritages.

\section{Tharu Culture}

The Tharu tribe (by surname called Chaudhary) has a long history. The Tharus are rich in culture, customs and manner. The traditional fashion creates compassion and attraction, which are the major elements of tourist attraction. They celebrate different festivals like: Maghe Sankranti, Dashiya, Faguwa, Ekadashi Vart etc. Curry, rice, pickle, ghonghi [a kind of insect used for food], fish, liquor, bread etc. are the dishes of Tharu community. Popular dances of Tharu community are Jhumra, Birkain Chachar, Latthi Nach, Mungrahawa Nach, Mayoor Nach, Madhablala etc. These are the basic tourist attractions.

\section{Accommodations}

The major component to travelling is the accommodation or the lodging facilities offered by the hotels, lodges, resorts. Rhino Resort, Bahari Hotel, C G groups' hotel, GolaGhat resort, Chital lodge and Sarang Spa Resort are some of the popular accomodators of Meghauli. The resort provides deluxe accommodations with modern facilities. Just below the resorts, the Rapti river flows along the park's border which offers visitors a very memorable boat ride with prospects of learning about the park's aquatic habitat. Visitors can explore the park via elephant rides or on foot.

Table No. 1: The Capacity to Accommodate Tourists

\begin{tabular}{|l|l|l|l|l|l|}
\hline S.N & Name of Resort/ Hotel/ Lodge & $\begin{array}{l}\text { No. of } \\
\text { Tents }\end{array}$ & $\begin{array}{l}\text { No. of } \\
\text { Rooms }\end{array}$ & $\begin{array}{l}\text { No. of } \\
\text { Beds }\end{array}$ & $\begin{array}{l}\text { Year } \\
\text { Established }\end{array}$ \\
\hline 1 & Rhino Resort & 10 & 12 & 55 & 2056 \\
\hline 2 & Golaghat Wildlife Resort & 10 & 8 & 50 & 2066 \\
\hline 3 & Chital Lodge & 2 & 6 & 16 & 2042 \\
\hline 4 & Narayani Resort & 6 & - & 12 & 2066 \\
\hline 5 & $\begin{array}{l}\text { Meghauli Evergreen Guest house and } \\
\text { Bar }\end{array}$ & - & 3 & 6 & 2066 \\
\hline 6 & Bul Bul Restaurant and Lodge & - & 3 & 6 & 2058 \\
\hline 7 & Chautary Restaurant and Hotel & - & 3 & 5 & 2060 \\
\hline 8 & Tiwari Hotel & - & 1 & 2 & 2051 \\
\hline 10 & Bahari Jungle Lodge & - & 35 & 70 & 2070 \\
\hline 11 & CG Safari Resort & - & 16 & 22 & 2071 \\
\hline 12 & Sarang Wildlife Century Spa resort & - & 24 & 48 & 2071 \\
\hline & Total & $\mathbf{2 8}$ & $\mathbf{1 1 1}$ & $\mathbf{2 9 2}$ & \\
\hline
\end{tabular}


The table shows different resorts, hotels and lodges of Meghauli along with the total number of tents, rooms and beds .

Table No. 2: Tourist by Age Group

\begin{tabular}{|l|l|l|l|}
\hline S. N. & Age Groups & No of Respondents & Percentage \\
\hline 1 & $10-30$ years & 12 & $24 \%$ \\
\hline 2 & 31-50 years & 27 & $54 \%$ \\
\hline 3 & Above 50 years & 11 & $22 \%$ \\
\hline & Total & $\mathbf{5 0}$ & $\mathbf{1 0 0 \%}$ \\
\hline
\end{tabular}

Table 2 shows that out of 50 respondents, $12(24 \%)$ respondents were in age group of 1030 years, $27(54 \%)$ respondents were in age group of 31-50years and remaining $11(22 \%)$ respondents were age group of above 50 years.

Table No. 3: Purpose of Visit

\begin{tabular}{|l|l|l|l|}
\hline S.N. & Purpose of visit & No of respondent & Percentages \\
\hline 1 & Jungle safari & 22 & $44 \%$ \\
\hline 2 & Viewing scenery & 6 & $12 \%$ \\
\hline 3 & Village people and culture & 5 & $10 \%$ \\
\hline 4 & White water rafting & 4 & $8 \%$ \\
\hline 5 & Pleasure and relaxes & 3 & $6 \%$ \\
\hline 6 & Bird watching & 2 & $4 \%$ \\
\hline 7 & Others( polo, ecopark, sunset views etc) & 8 & $16 \%$ \\
\hline & Total & $\mathbf{5 0}$ & $\mathbf{1 0 0 \%}$ \\
\hline
\end{tabular}

Table 3 shows that majority of the respondents visited Meghauli for the purpose of jungle safari and only $2(4 \%)$ respondents visited for the purpose bird watching. 


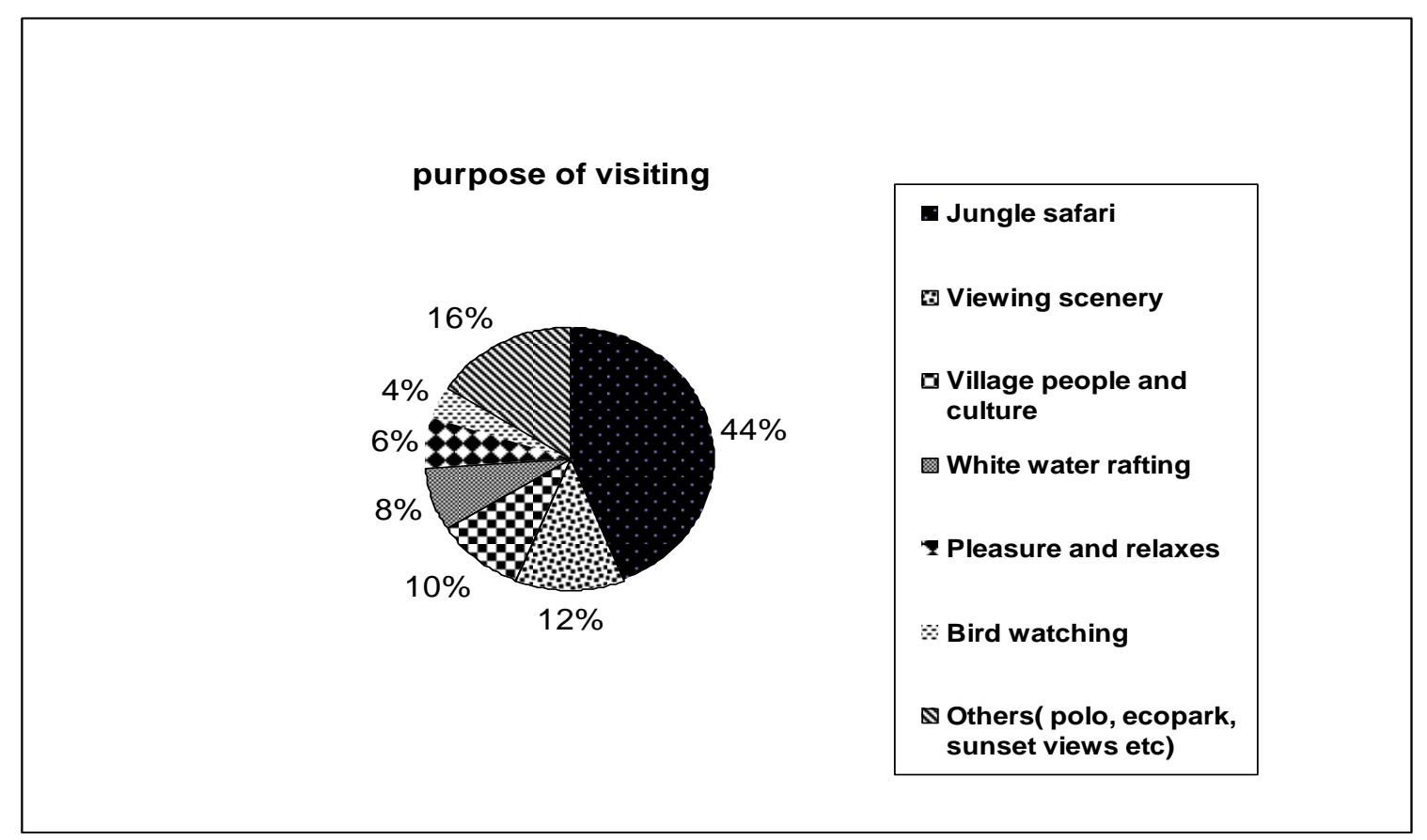

\section{Figure 1: Tourist visit Meghauli}

The figure shows that the majority of the tourists come to visit Meghauli for the purpose of jungle safari. Out of 50 respondents, 44 percentages reported to hve had come to visit national park, 12 percent visitors for the purpose of viewing scenery, 10 percent for visiting village people and culture, 8 percent for white water rafting, 6 percent for pleasure and relaxation, 4 percent for bird watching and remaining 16 percentages of visitors had come to see other tourism activities such as elephant polo, ecopark, sunset views etc.

Table No. 4: Satisfaction Level of Respondents on Existing Facilities

\begin{tabular}{|l|l|l|l|}
\hline S.N. & Level of Satisfaction & No of Respondents & Percentage \\
\hline 1 & Very satisfied & 16 & $32 \%$ \\
\hline 2 & Satisfied & 20 & $40 \%$ \\
\hline 3 & Not satisfied & 14 & $28 \%$ \\
\hline & Total & $\mathbf{5 0}$ & $\mathbf{1 0 0 \%}$ \\
\hline
\end{tabular}

Table 4 shows that out of 50 respondents, 16 (32\%) respondents were very satisfied, 20 (40\%) respondents were satisfied and remaining 14 (28\%) respondents were not satisfied with existing facilities of destination. 


\section{Prospects of Tourism in Study Area}

The potential of tourism development is greater as the local community seems to be more interested and aware about it. There is no proper management of tourism in spite of the formation of tourism development committee for developing Meghauli VDC as a tourist destination. The most basic infrastructure such as electricity, roads, airport, proper communication, health centers, postal and security facilities are readily available. The study area is suitable for tourism development. Meghauli has the potentiality of ecotourism, village tourism, sport tourism, wild life tourism etc.

Table No. 5: Prospects of Tourism According to Visitors

\begin{tabular}{|l|l|l|l|}
\hline S.N. & Level of Satisfaction & No of Respondents & Percentage \\
\hline 1 & Yes & 46 & $92 \%$ \\
\hline 2 & No & 4 & $8 \%$ \\
\hline & Total & $\mathbf{5 0}$ & $\mathbf{1 0 0 \%}$ \\
\hline
\end{tabular}

Table 5 shows that out of 50 respondents, $46(92 \%)$ respondents said Meghauli has future prospects in tourism and $4(8 \%)$ respondents said there are many challenges so, it has no prospects of tourism.

\section{Prospects of Eco Tourism}

Ecotourism is a complex and multidisciplinary phenomenon and it has a tremendous role to play. It respects the environment and encourages and promotes the well-being of local people. Meghauli has a scope of ecotourism. It is the best instrument for conservation of natural and cultural heritage. Ecotourism can serve conservation in many ways, for example, by increasing awareness of ecological and other values of nature on both local and international levels, by creating political pressure both locally and internationally to conserve biological resources for current and future generations, and by providing socio-economic incentives to maintain wildlife populations and habitats through job creation. It can be the source of collecting foreign currency and capital investment. Ecotourism provides sufficient opportunities to make use of tourism as a tool for protection of natural ecosystem. Meghauli has large areas of community forest. Eight community forests are extraordinary ecotourism sites managed solely by local community. These forests are excellent mediums of providing direct benefits to the local commodity. The community forests are located within the buffer zone and are connected to the national park.

\section{Prospects of Village Tourism:}

Village tourism is a key factor of economic benefit to tourism entrepreneurs and villagers of Meghauli. It concerns with man's activities in relation to the village's wetlands, green forests, wild life, climate and socio-cultural phenomena. The geographical elements of Meghauli show 
that it has the prospects of village tourism which brings all the significant changes in the village economy. Meghauli village tourism has its own uniqueness and originality in comparison to village tourism. It creates a self-sustaining and self-standing economy. The village is recommended as being suitable for a model tourist village.

\section{Prospects of Sports Tourism:}

Due to various tourism products available in the Meghauli, there is a great scope for developing sports tourism as well. The prime sports tourism attraction of Meghauli is Elephant Polo. The first game was played on a grass air field organized by Meghauli World Elephant Polo Association for the first time in all over the world. The sufficient ground offers possibilities of arranging various games like football, cricket, and athletics. The location of Meghauli is suitable for Golf. There are other potential games that can be organized in Meghauli, such as- beach volleyball, football etc.

\section{Prospects of Religious Tourism:}

Meghauli contains number of Hindu religious sites, visited by worshipers. Prashadhap area is the most significant site for Hindu pilgrimage to worship different dieties like- Radha Krishna, Ganesh, Shivalaya, Chandrakala, Jagtradevi, Bhoj Baba, Kalika, Ramjanaki, Harihar, Gorkhakali, Laxmi, Durga etc.

\section{Prospects of Wildlife Tourism:}

Large numbers of wild animals are found in Chitwan National Park and community forest in Meghauli. This area provides shelter to different wildlife like: rhinoceros, bangal tiger, spotted deer, wild boar, leopard, barking deer, somber deer, monkey and other species of animals including reptiles. In Meghauli and surrounding areas of CNP wildlife safari can be done on elephant back. Ecopark in Radha Krishna community forest has already started to operate wildlife safari earning revenue during 'Meghauli Tourism Festival.' Most of the community forests share common attractions in terms of wildlife and forest species along with some additional specialties like view towers, trails, bird hide sites, machan etc. that are attached to the forests. The buffer zone community forests of Rapti and Narayani Rivers in next to Chitwan national park can provide opportunities for wild life tourism development.

\section{Prospects of Agro-Tourism:}

Agro tourism is the concept of diverting the tourists to those rural areas, where many agricultural activities, services and features are provided by farmers and rural people to attract tourists in order to generate extra income. Meghauli, having indigenous communities with their specific farming techniques and commercial scale poultry farming, mushroom cultivation, 
hunting, fruits, medical plant, vegetables, bees keeping, fish keeping etc. is the new site for agro tourism.

\section{Challenges of tourism development in Meghauli}

There are many challenges in the development of tourism in Meghauli. So far as the risk of flash floods in Rapti and Narayani River are of prime concern. Every summer season it floods the soil of Meghauli and destroys the jungle as well. Similarly, it creates environmental degradation and disturbs the wildlife habitats. The sal forest is the habitat of many endangered species such as tiger, gaur, and ling sang and sloth bears. Because of lack of planning and zoning, natural conservation areas are being seriously threatened by poaching of animals. By deforestation, they are losing their habitat day by day. So it has been challenging to preserve the wild life and their habitats. Similarly, there is lack of recreational facilities like cultural center, club, garden etc. likewise; insufficient facilities of infrastructures such as road, airport, and river ways are major challenges in tourism development. The problem of load shedding is also a barrier for development.

The village people of Meghauli have limited knowledge of tourism. This unawareness motivates them to ruin involvement in tourism development. They have established Tharu museums but these are not building as the cultural museums of Tharus. This is because they are following the modern philosophy of building houses rather than preserving their own traditions. So, because of the influence of modernity the ancient significance has been in decreasing order. And, it has directly been affected in the tourism of Meghauli. Private elephants are not permitted to enter inside the CNP and the limited numbers of government elephants are unable to provide sufficient jungle safari facilities in CNP and surrounding community forests.

To sum up, instability of the government and the conflict between political parties are the major issues for the development of the nation, which also harms for the tourism. Therefore, it directly hampers the development of tourism in Meghauli. The lack of information centers, nature guides, travel agencies' and promotional activities are other, significant challenges for tourism development in Meghauli.

\section{CONCLUSIONS}

Nepal is situated in the lap of the Himalayas. It spans $800 \mathrm{k}$. m. to the west and embraces eight of the world's highest mountain peaks, including the highest, Mt. Everest (8848m). It possesses diverse natural beauty. Natural attractions range from mountain valleys to tropical low land vegetation, allowing visitors to enjoy wide varieties of climates. Rivers flowing from the high mountains to the indo genetic plain pass through great mountain valleys in the south that form the vast fertile skirt of the Himalayan watershed. Nepal is also the garden of various ethnic and indigenous groups with their colorful lifestyle and cultures. 
Chitwan valley is one of the greatest vallies in terms of its thick green forests and grassland. Realizing the importance of protecting the environmentally sensitive area, 932 square $\mathrm{km}$ of forestland was set aside and officially designated as the Chitwan national park. Meghauli is situated by the side blanks of CNP and two big River Rapti and Narayani. The community forest and CNP is the home of many types of wildlife, Almost 500 species of birds and $a$ wide variety of vegetation can be found. The dense forests, grasslands, rivers and many lakes embrace the balanced park ecology, providing an environment suitable for animals, birds, insects and other forms of life. But it is not managed naturally and properly.

The prime tourism attractions of Meghauli are the rare flora and fauna, natural beauty, villages, community forest, cultural diversity, religious places, rivers, lakes, world heritage CNP, ecopark, picnicpark, sunset view point etc. Due to these various tourism products in Meghauli, it has potential for the establishment of magnificent resorts and future development of tourism.

\section{BIBLIOGRAPHY}

Bhandari, K. R. (n.d.). TOURISM POLICIES AND PRIORITIES. Presentation, Nepal Tourism Board, Research, Planning and Monitoring, Kathmandu, Nepal.

Brohman, J. (1996). New directions in tourism for Third World development. Annals of Tourism Research, 23 (1), 48-70.

Center, T. I. (2014). Major Tourist Destination in Chitwan. Bharatpur: Chitwan Tourism Development Committee.

Eraqi, M. I. (2006). Tourism services quality (TourServQual) in Egypt: The viewpoints of external and internal customers. Benchmarking: An International Journal, Vol. 13( Iss: 4), pp.469 - 492.

Getz, T. B. (1995). COLLABORATION THEORY AND COMMUNITY TOURISM PLANNING. AnnMs of Tourism Research, Vol. 22(No. 1), pp. 186-204.

Government of Nepal. (2009). Tourism Vision 2020. Kathmandu, Nepal: Ministry of Tourism and Civil Aviation, Ktm.

Graefe, S. S. (1998). Influence of terrorism risk on foreign tourism decisions. Annals of Tourism Research, 25, 112-144.

Hall, C. M. (1996). Tourism, Political Stability and Violence. In e. A. Pizam and Y. Mansfeld, Tourism, Crime and Inter-national Security Issues (pp. 105-121). New York: Wiley.

Koirala, S. P. (2057, 10 15). Altlirnative destination Meghaui. (B. R. Poudel, Interviewer)

WTO. (1994). Recommendations on Tourism Statistics. Madrid: WTO.

WTTC. (2012, September 19). Travel and Tourism economic impact Nepal . Kathmandu, Nepal: http://www.wttc.org/site_media/uploads/downloads/nepal2013_2.pdf . 